\title{
Retinopathy of Prematurity Finding
}

National Cancer Institute

\section{Source}

National Cancer Institute. Retinopathy of Prematurity Finding. NCI Thesaurus. Code C118300.

An ophthalmoscopic finding that refers to retinopathy of prematurity. 